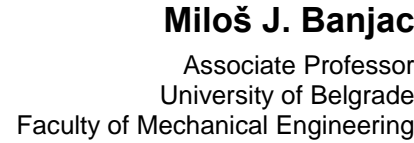

Miloš J. Banjac

University of Belgrade

Faculty of Mechanical Engineering

\section{Application of Computational Fluid Dynamics in Cooling Systems design for Special Purpose Objects}

The paper illustrates the basic methodology and principal problems of CFD (Computational Fluid Dynamics) approach in designing a proper cooling system (capacity of cooling, determination of optimal position, number and size of openings for cooling, etc.) in special purpose objects. Taking as an example the design of the cooling for electrical equipment placed in a container of crane MK-46 - "GOSA FOM", the problem of the selection of proper cooling system was demonstrated.

It has been shown that the numerical fluid dynamics represents a superior approach to the design of these systems., with its ability to, provide precise three-dimensional images of velocity and temperature field in the fluid even before the construction of the facility, as well as to predict the changes of those fields that would appear with modification of geometry, boundary and spatial conditions (opening for injection and exhausting of air, position of the walls and obstacles).

Keywords: cooling system, heat load, container of crane, openings, CFD simulations.

\section{INTRODUCTION}

One of the most important requests, if not the most important, in the design of air conditioning systems, heating, cooling or ventilation (HVAC) is achieving the desired speed and temperature air fields, and concentration fields of certain substances in the projected space. In case there are people residing in the space, the conditions that should be fulfilled are known as comfort conditions. In industry, these conditions are usually called process conditions, because they are related to the types of realized technological processes.

To meet the required comfort conditions or process conditions, in addition to selected proper heating or cooling capacity of a device for HVAC obtained by standard calculations, it is necessary to define the appropriate speed and temperature of prepared air, which should be inserted into the workspace, as well as the number, distribution and size of the opening through which insertion or ejection of air should performed.

Until the advent of the CFD (Computational Fluid Dynamics) and its penetration into the design of the HVAC system, the prediction of these fields was a very ungrateful job. The prediction of temperature fields of air, the concentration of certain substances in it, and its flows, were based on the use of laboratory obtained diagrams of the diffuser behavior and empirical characteristics and behavior of the jet. Implementation of these equations and diagrams to determine the behavior of air in real space usually led to significant differences between projected and actual size of these fields. In addition to its unreliability and its

Received: February 2013, Accepted: May 2013

Correspondence to: Dr Miloš Banjac

Faculty of Mechanical Engineering,

Kraljice Marije 16, 11120 Belgrade 35, Serbia

E-mail: mbanjac@mas.bg.ac.rs

doi: $10.5937 /$ fmet1401026B

(C) Faculty of Mechanical Engineering, Belgrade. All rights reserved imperfections, this standard approach has shown scarcity or complete lack of information on the physical size of the areas outside the zone of jets.

Unlike the conventional approach, the numerical CFD - approach enabled, regardless of the complexity of geometrical area and boundary spatial and time conditions, relatively easy and, at the same time, very precise prediction of even very complex fields of velocity, temperature and concentrations formed in the air. This approach, based on the space discretization and mesh generation, thus forming a very large number of finitely small control volumes (CV) and setting and simultaneous solving of balance equations defined for each $\mathrm{CV}$, made it possible to gather information on fluid velocity, pressure, temperature, density, turbulence level, concentration of particular substances etc. for a significantly large number of points in volume. This particular advantage of the CFD approach has made it an almost ideal method for designing ventilation $[1,2]$, HAVC [3,4], smoke extraction systems [5,6]. Also, CFD is powerful tools which can combine architectural and building thermal performance modeling [7], as well as to be used for prediction of flows with chemical reactions, through complex geometry of burners and furnaces $[8,9]$.

The main problems of the CFD approach to solving the problem of choosing an appropriate cooling system, and determining the optimal position and the number of openings for cooling and air velocity are demonstrated in this paper, through the designing of the cooling system for electrical equipment housed in a container cranes MK46 - "GOSA FOM".

\section{PROBLEM DESCRIPTION AND TERMS OF REFERENCE}

A container for storing electrical equipment used for manipulation of reloading cranes - container MK-46 


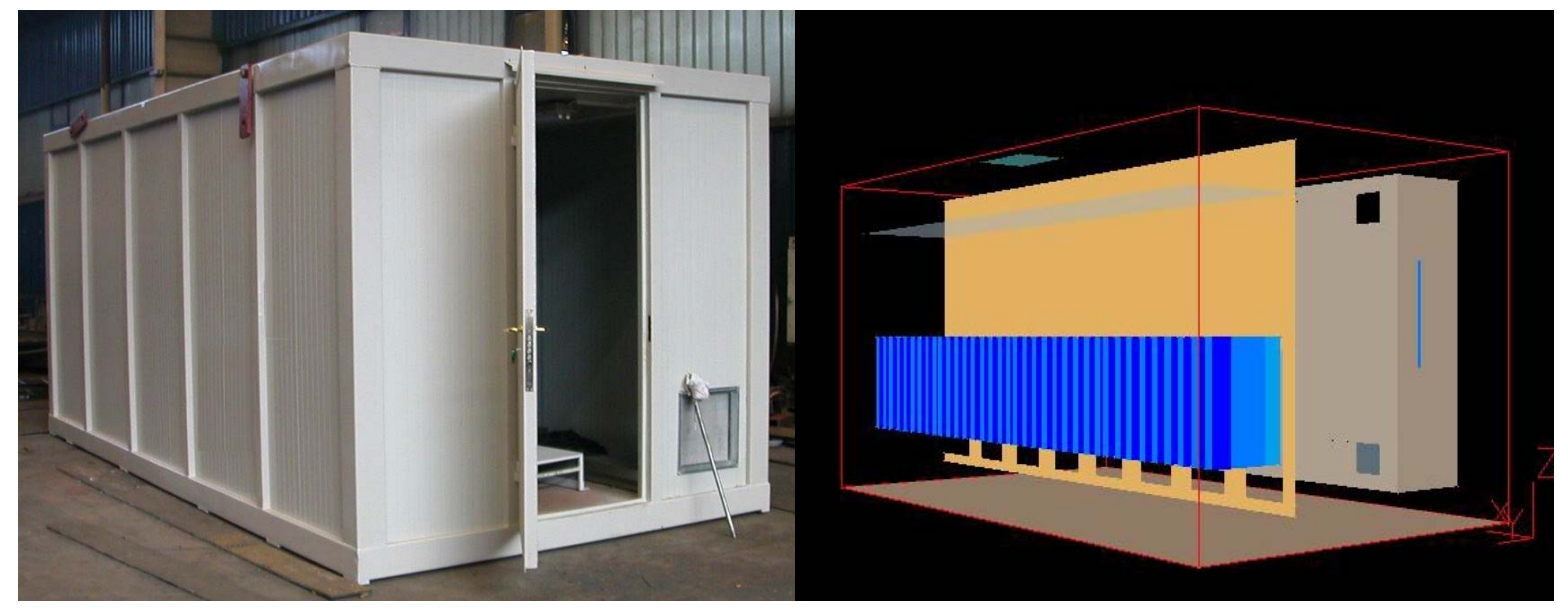

Figure 1 Appearance of MK-46 container for storing electric reloading cranes and equipment a) actual appearance container b) computer-generated container's space

(Figure 1) is located within the reloading crane, which was the main subject of design, construction and manufacture of the company GOSA FOM Ltd.

The entire reloading crane is designed to work in the fourth snowy region in the Russian Federation, in highly polluted conditions, with a high concentration of dust and soot in the outside air.

During crane operation, i.e. during operation of electrical equipment, a part of electrical energy is transformed (dissipated) in the appropriate amount of heat energy. Due to the extremely high power of some parts of electrical equipment, released thermal power reaches values up to several kilowatts, causing significant heating and rise of air temperature in the container. Although the presence of people in this container is not foreseen, to ensure uninterrupted and safe operation of electrical equipment and its related regulatory systems, the project envisages installation of air cooling system in the container. Because of contamination of the surrounding air and the absence of a pollutant within the container, the idea was to design the cooling system as a "closed" system, i.e. to work with full recirculation of air.

Due to constructive and technological constraints, the openings for air insertion have to be placed on their lateral side, while the exhaust openings should be placed on the upper side of the container.

The terms of reference relating to the provision of cooling electrical equipment in the container envisaged:

- determination of the required heating loads and appropriate cooling power of the cooling system

- selection of the cooling device,

- determination of optimal position, size and number of openings where the insertion and ejection of air from the container will be performed, where it is necessary to ensure:

- the temperature of the air entering the cabinets with electrical equipment should not be higher than $26^{\circ} \mathrm{C}$,

- the temperature of the air leaving the cabinets with electrical equipment not higher than $45^{\circ} \mathrm{C}$,

- the velocity of air in the container does not exceed $6 \mathrm{~m} / \mathrm{s}$.

\section{NUMERICAL CALCULATION OF VELOCITY AND TEMPERATURE FIELD IN FHE CONTEINER}

\subsection{Numerical model}

For the purpose of calculation of the flow and temperature fields in the air, which is formed under the influence of external climatic conditions and electroworking equipment inside the container, a 3dimensional container space model was generated with commercial CFD software package PHOENICS 3.4 (Figure 1b)

According to the assumed physical situation, the projected appearance of the container also generated the layout of corresponding solid walls, closets with electrical equipment, electrical equipment (heating bodies, heat sources), fans, and position of appropriate openings - windows and doors. The shape of electrical equipment located in electrical-closets was adopted as a standard form of heating body, due to the lack of information of their precise geometry.

Inner, virtual garage space was divided into $\mathrm{CVs}$ in such a manner that all boundary surfaces of CVs were aligned with the contours of appropriate solid bodies and barriers within the space. Thus generated mesh was additionally balanced, i.e. made thicker, by adding control volumes in the zones near windows and openings. The initial relatively large number of the control volumes, in order to reduce CPU time, has been reduced to just $144 \times 40 \times 34=159.840$ control volumes. In the process of number reducing of CVs special attention was paid to:

- the required thickness of the first layer of CVs be in the range of $30<y^{+}<400$;

- the thickness of the CVs increasing with ratio not be greater than 1.2 with increasing distance from the solid surface

- the velocity field and temperature field not differ from those obtained with a larger number of CVs.

\subsection{Mathematical model}

For the calculation of flow and temperature fields of air formed within the container, a two-equation $k-\varepsilon$ turbulent model was used [10]. This universal turbulent 
model was chosen due to its confirmed reliability in predicting the flow fields, economy in the sense of CPU time, and reasonable accuracy for a wide range of turbulent flows [11].

- continuity equation:

$$
\frac{\partial}{\partial x_{i}}\left(\rho U_{i}\right)=0
$$

- modeled Reynolds averaged Navier-Stokes (RANS) equations (3 scalar equations):

$$
\begin{gathered}
\frac{\partial}{\partial x_{j}}\left(\rho U_{i} U_{j}\right)= \\
=-\frac{\partial P}{\partial x_{i}}+\frac{\partial}{\partial x_{j}}\left[\left(\mu_{\mathrm{f}}+\mu_{t}\right) S_{i j}-\frac{2}{3} k \delta_{i j}\right]+\rho F_{i},
\end{gathered}
$$

- and energy conservation equation:

$$
\begin{gathered}
\frac{\partial}{\partial x_{j}}\left(\rho U_{j} H\right)= \\
=U_{i} \frac{\partial P}{\partial x_{i}}+2 \mu_{\mathrm{t}} S_{i j} S_{i j}+\frac{\partial}{\partial x_{i}}\left[\left(a_{\mathrm{f}}+\frac{\mu_{t}}{P r_{\mathrm{f}}}\right) \frac{\partial H}{\partial x_{i}}\right],
\end{gathered}
$$

and plus two equations- which define this turbulence model:

- equation for transport of turbulence kinetic energy:

$$
\begin{gathered}
\frac{\partial}{\partial x_{i}}\left(\rho U_{i} k\right)= \\
=\mathscr{k}+\frac{\partial}{\partial x_{i}}\left[\left(\mu_{\mathrm{f}}+\frac{\mu_{\mathrm{t}}}{P r_{k}}\right) \frac{\partial k}{\partial x_{i}}\right]-\rho \frac{\mu_{\mathrm{t}} g_{i}}{\sigma_{h}} \frac{\partial \rho}{\partial x_{i}}-\rho \varepsilon
\end{gathered}
$$

- and equation for transport of specific dissipation rate:

$$
\begin{gathered}
\frac{\partial}{\partial x_{i}}\left(\rho U_{i} \varepsilon\right)=C_{\varepsilon 1} \frac{\varepsilon}{k} \stackrel{\mathscr{R}}{k}-C_{\varepsilon 2} \rho \frac{\varepsilon^{2}}{k}+ \\
+C_{\varepsilon 3} \rho \frac{\mu_{\mathrm{t}} g_{i}}{\sigma_{h}} \frac{\partial \rho}{\partial x_{i}}+\frac{\partial}{\partial x_{i}}\left[\left(\mu_{\mathrm{f}}+\frac{\mu_{\mathrm{t}}}{P r_{\varepsilon}}\right) \frac{\partial \varepsilon}{\partial x_{i}}\right]
\end{gathered}
$$

In the aforementioned equations, according to a standard procedure, $S_{i j}$ was defined as the main strainrate tensor:

$$
S_{i j}=\frac{1}{2}\left(\frac{\partial U_{i}}{\partial x_{j}}+\frac{\partial U_{j}}{\partial x_{i}}\right)
$$

and $\mathscr{k}$,the volumetric production rate of $k$ by shear forces is:

Table 1. Empirical constants of $k-\varepsilon$ model of turbulent stresses for low Reynolds turbulent numbers

\begin{tabular}{|c|c|c|c|c|c|c|c|}
\hline $\operatorname{Pr}_{k}$ & $\operatorname{Pr}_{\varepsilon}$ & $C_{D} C_{\mu}$ & $C_{\varepsilon 1}$ & $C_{\varepsilon 2}$ & $C_{\varepsilon 3}$ & $\kappa$ & $\operatorname{Pr}_{\mathrm{f}}$ \\
\hline 1.0 & 1.314 & 0.09 & 1.44 & 1.92 & 1.0 & 0.41 & 1.0 \\
\hline
\end{tabular}

$$
\mathscr{R}=\mu_{\mathrm{t}}\left(\frac{\partial U_{i}}{\partial x_{j}}+\frac{\partial U_{j}}{\partial x_{i}}\right) \frac{\partial U_{i}}{\partial x_{j}} .
$$

Modeling of the Reynolds stresses tensor was based on the Boussinesq hypothesis:

$$
\tau_{i j}=\mu_{t}\left(\frac{\partial U_{i}}{\partial x_{j}}+\frac{\partial U_{j}}{\partial x_{i}}\right)-\frac{2}{3} k \delta_{i j}=\mu_{t} S_{i j}-\frac{2}{3} k \delta_{i j}
$$

where the eddy viscosity $-\mu_{\mathrm{t}}$ is defined by the equation:

$$
\mu_{\mathrm{t}}=\left(C_{D} C_{\mu}\right) \rho \frac{k^{2}}{\varepsilon}
$$

Since the value of molecular diffusivity of smoke into the air was negligible in comparison to the turbulent (molar) diffusivity, it was neglected during the calculation.

The values of the empirical constants of this model, as well as the values of the Prandtl (enthalpy), are given in Table 1.

Apart from the $k-\varepsilon$ turbulent model, and as a standard procedure for two-equation turbulent models, the Reynolds enthalpy flux was modeled in accordance with the principles of the simple gradient-diffusion hypothesis:

$$
-\rho \overline{h u_{i}}=-\rho\left|\overline{\frac{h u_{1}}{h u_{2}}}\right|=\frac{\mu_{t}}{P r_{\mathrm{f}}} \frac{\partial H}{\partial x_{i}}
$$

Under the assumption that fluid has constant thermophysical properties (molecular viscosity $\mu_{\mathrm{f}}$, thermal conductivity $\lambda_{\mathrm{f}}$ and $c_{p}$ specific heat capacity at constant pressure), the three conservation equations (1$3)$, two transport equation $(4,5)$, three hypotheses (911) and equation of state for ideal-gas:

$$
\begin{gathered}
\rho=\frac{P}{R T}, \\
H=c_{p} T,
\end{gathered}
$$

create a mathematically closed system. In that sense, it was assumed that specific thermal capacity of air at constant pressure has the value of $c_{p}=1004,9 \mathrm{Jkg}^{-1} \mathrm{~K}^{-1}$, thermal conductivity is $\lambda_{\mathrm{f}}=25.68 \cdot 10^{-3} \mathrm{Wm}^{-1} \mathrm{~K}^{-1}$ and that kinematic (molecular) viscosity of air is $\mu_{\mathrm{f}}=15,35 \cdot 10^{-3} \mathrm{~m}^{2} \mathrm{~s}$ [12]. 
Table 2. Summary heat load of electrical equipment for container MK-46

\begin{tabular}{|c|c|c|c|c|}
\hline $\begin{array}{c}\text { Tag of } \\
\text { equipment }\end{array}$ & $\begin{array}{l}\text { Nominal value of thermal } \\
\text { power released }[\mathrm{kW}]\end{array}$ & $\begin{array}{l}\text { Equipment time } \\
\text { load [\%] }\end{array}$ & $\begin{array}{c}\text { The average heat } \\
\text { output of equipment } \\
\text { [W] }\end{array}$ & $\begin{array}{l}\text { Volumetric flow through } \\
\text { the local fan }\left[\mathrm{m}^{3} / \mathrm{s}\right]\end{array}$ \\
\hline Em1 & 0,2 & 100 & 200 & - \\
\hline Em2 & 6,6 & 48 & 3168 & 0,46 \\
\hline Em3 & 6,6 & 40 & 2640 & 0,46 \\
\hline Em4 & 6,6 & 64 & 4224 & 0,46 \\
\hline Em5 & 6,24 & 56 & 3494 & 1,00 \\
\hline Em6 & 0,2 & 100 & 200 & 0,064 \\
\hline Em7 & 0,2 & 100 & 200 & 0,064 \\
\hline Em8 & 0,2 & 100 & 200 & 0,064 \\
\hline
\end{tabular}

\subsection{Boundary conditions}

According to the real physical situation, i.e. designed layout of the container, it was necessary to specify boundary spatial and initial conditions for velocity and temperature (energy) fields.

\section{- Boundary conditions for the contact surfaces of the air and solid}

The "wall" function model was used for specifying boundary conditions for air velocity near the solid surfaces inside the container. Since the used turbulent model belongs to a class of the high Reynolds turbulent model, wall functions of the logarithmic area of the turbulent boundary layer were used to determine the values of variables, i.e. their flows next to the plate. $[11,13]$. At the same time, the following was assumed as boundary conditions for the temperature field:

- container walls - heat flux caused by external climatic conditions, obtained independently by standard calculation of heat gains,

- border surface of electrical equipment - heat fluxes were obtained based on the calculated thermal power released by electro-equipment (Table 2)

\section{- Boundary conditions at the air flow exit from the container}

Since the variable values in the domain of outside sections (windows) are completely unknown, the socalled condition of "constant" pressure [14] was used as for the boundary condition. This condition consists of specifying zero derivatives in the direction normal to the outgoing plane, i.e. specifying the second type of boundary conditions for all values of dependent variables, except for velocities normal to the outgoing plane, i.e.: $\quad \partial \Phi /\left.\partial x_{2}\right|_{\text {out }}=0 \quad$ and $\partial \Phi /\left.\partial x_{3}\right|_{\text {out }}=0(\Phi=k, \varepsilon \mathrm{i} H)$, and specifying the pressure value as equal to the ambient pressure $\left.P\right|_{\text {out }}=P_{\mathrm{amb}}$. Values of missing velocities were defined indirectly, by using pressure values.

\section{- Boundary conditions at the air flow entrance in the container}

Velocity field at the air flow entrance of the container was set with the corresponding values of air volume flow rate. These flow values were to match the values from the catalogs of a few reputable manufacturers of industrial cooling equipment. Namely, after conducting the standard calculation of heat loads, caused by external climatic conditions and the thermal loads caused from using electrical-equipment inside the container, it was preliminarily determined that the required cooling capacity of thecooling system should be about $14 \mathrm{~kW}$. The review of manufacturers' catalogs suggested that chillers of required cooling capacity with volumetric flow rates in the range of 0.3 to $1.8 \mathrm{~m}^{3} / \mathrm{s}$ can be found on the market.

Table 3 shows the portion of operating regimes under which the numerical simulations for the container MK-46.were carried out.

\section{- Special types of boundary conditions}

Volume flow rate of the local fans have been set in accordance with the design.

Table 3. The review of operating regimes under which the numerical simulations for container MK-46 were carried out

\begin{tabular}{|c|c|c|}
\hline Operating regime & $\vartheta_{\text {in }} /\left[{ }^{\circ} \mathrm{C}\right]$ & $q_{V} /\left[\mathrm{m}^{3} / \mathrm{s}\right]$ \\
\hline I & 18 & 0,75 \\
\hline II & 18 & 0,8 \\
\hline III & 18 & 0,85 \\
\hline IV & 20 & 0,85 \\
\hline V & 18 & 0,9 \\
\hline VI & 20 & 0,9 \\
\hline VII & 18 & 1 \\
\hline
\end{tabular}

Because of the expected mismatch of the volume flow of air through the cooling system and the simple sum of volumes of air flow through the local fans, the designer has predicted the existence of "overflow" opening, located between the top of the electrical cabinets and container ceiling, in the plane of the front side (Fig. 1b) 


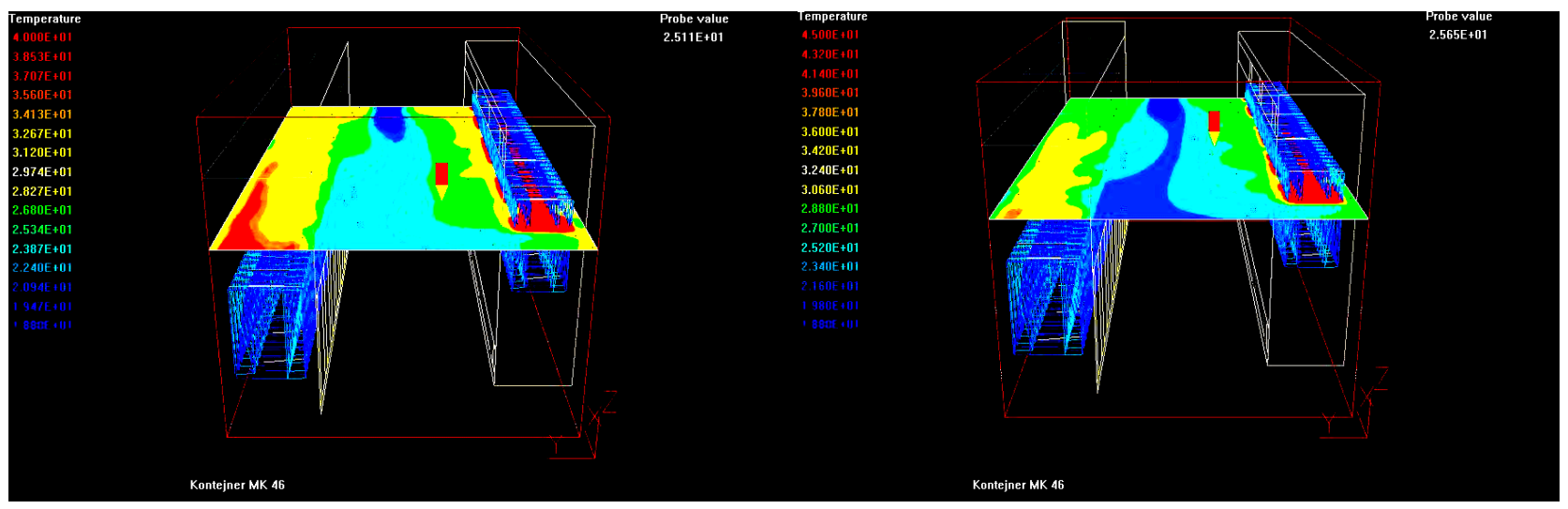

a)

b)

Figure 2. Temperature field in the horizontal plane in the container obtained by simulation in the case of one and two openings for air discharge

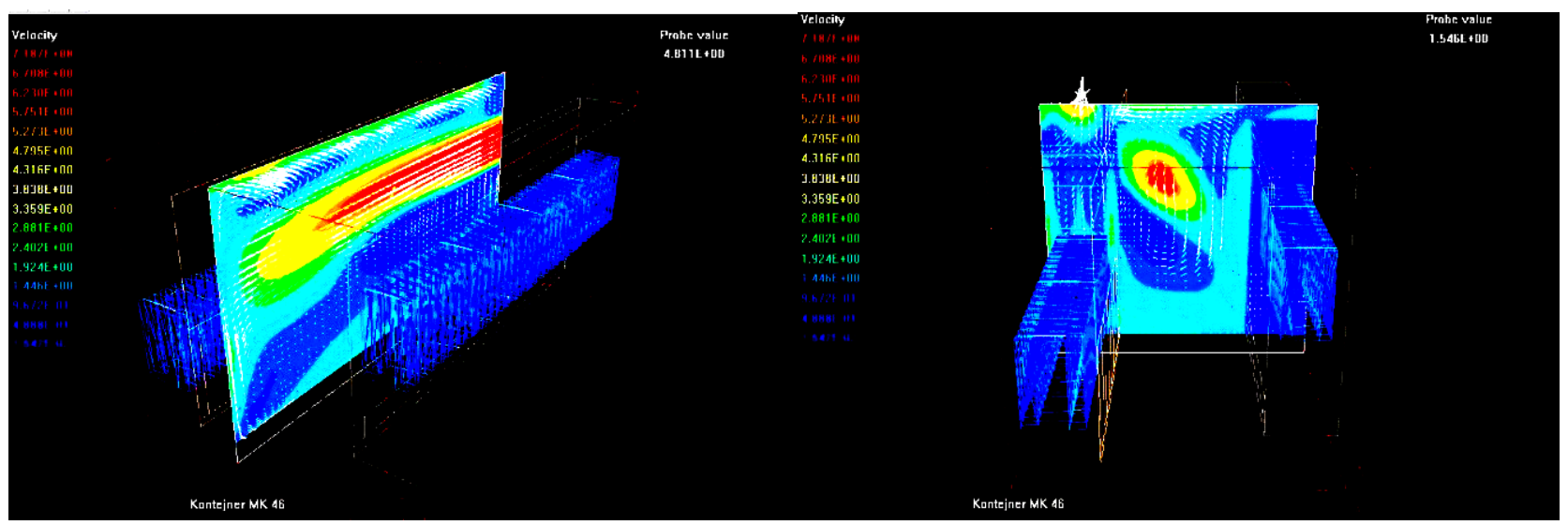

Figure 3. Velocity field, in two different plane in case of an excessive permitted speed of air flow $\left(q_{V}=1,2 \mathrm{~m}^{3} / \mathrm{s}\right)$

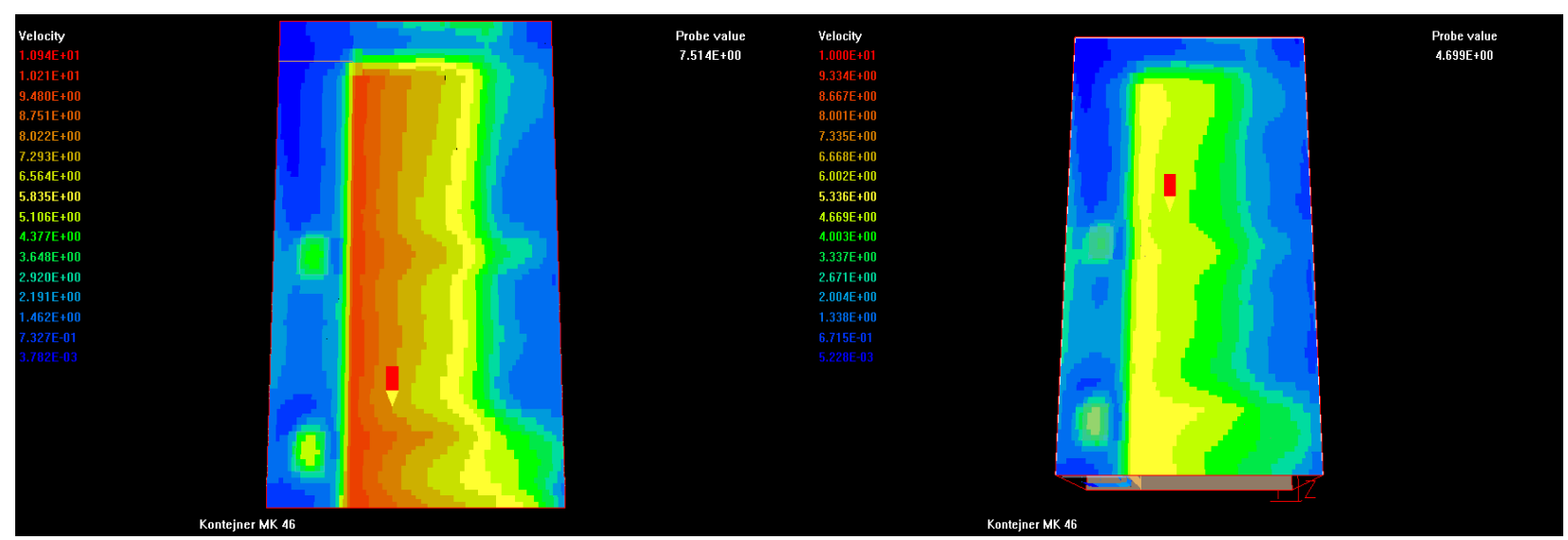

Figure 4. Velocity field in the container at the highest horizontal plane (along the top of ceiling) in the case of too narrow and satisfactory wide "overflow" vents ( $h=5 \mathrm{~mm}$ and $h=10 \mathrm{~mm}$ )

\section{PROCEDURE FOR SIZING OF COOLING SYSTEM, DETERMINATION OF OPTIMAL NUMBER AND ARRANGEMENT OF OPENINGS FOR INSERTION AND EJECTION OF AIR}

As mentioned before the selection of the appropriate cooling system was carried out by performing numerical simulations. All simulations were carried out for stationary condition. The first simulations were performed for the simplest structural design of a container - the container with one insertion and one discharge opening. However, after reviewing the results obtained by the first simulations it has become clear, that because of the very unbalanced temperature field and the appearance of high air temperature in some areas, it is necessary to increase the number of openings for air discharging (Figure 2). For this reason, yhe newly adopted geometric model for the container was made with one insertion and two air discharging openings.

The dimensions of "overflow" vents were determined, (the space between the top of the electrical enclosure and the container ceilings by adopting the 

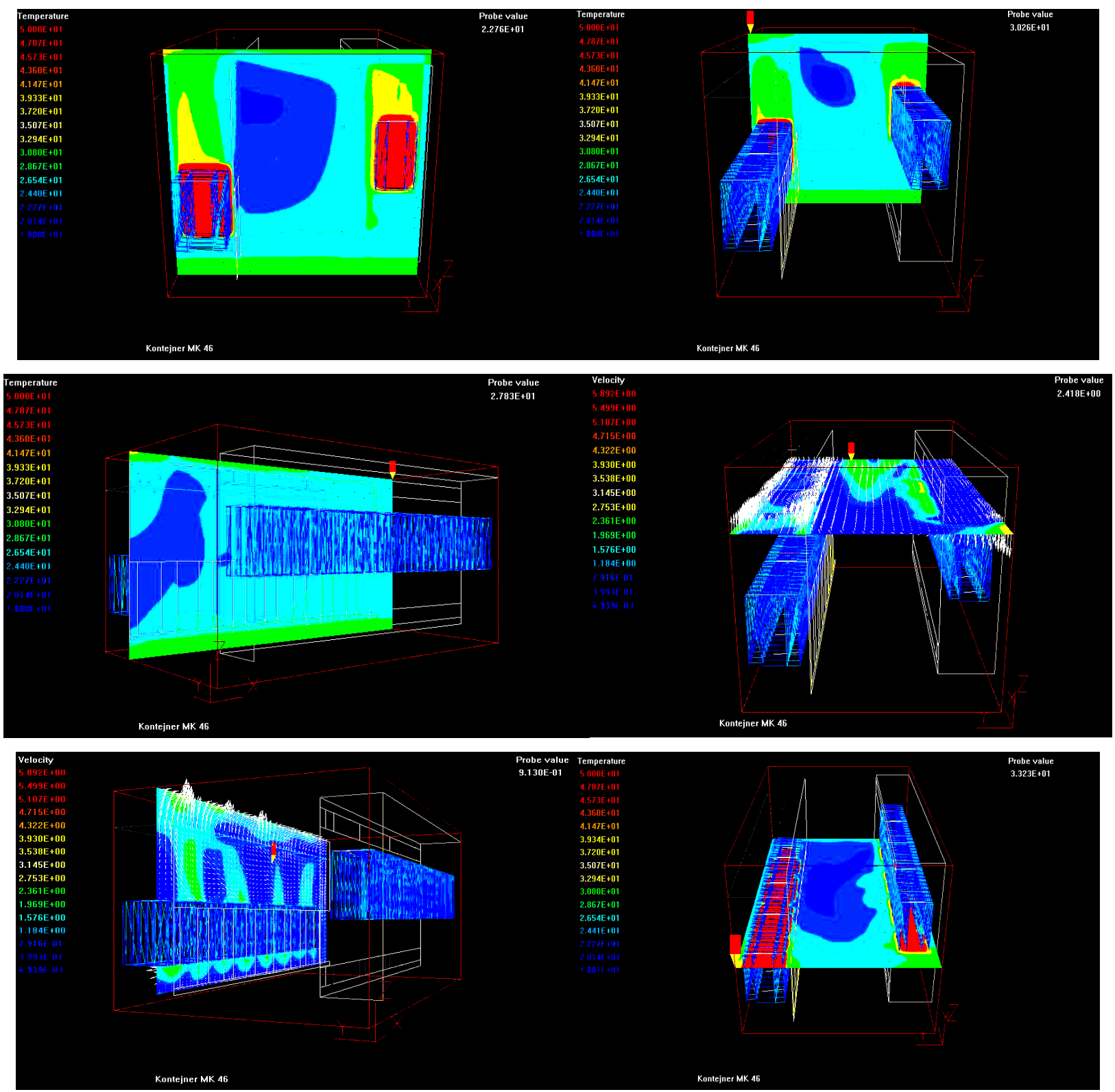

Figure 5. Preview of some typical temperature and velocity fields in the container used in analysis for determiantion of the optimum number and position of holes for inserting and ejecting air

values of air flow rate, and again based on the maximum allowable air velocity in the container,). With another numerical simulation it was found that the height of the vents should not be less than $10 \mathrm{~cm}$ (Fig. 4). Using similar numerical procedures we determined the required temperatures of cooled injected air and the optimal number and position of openings through which air is inserted and ejected from the container, based on the maximum allowed air temperature in specific places in the container, (Fig. 5 ).

First visually and then by checking the numeric values of the obtained results, it was concluded that the terms of reference requirement is possible to fulfill in a case of one insertion and two air discharge opening, only if they are set in a position determined by the numerical analysis. Besides, a condition minimum capacity of the cooling system of $\Phi \geq 14,35 \mathrm{~kW}$ and the volume of air flow $q_{V}=0,85 \mathrm{~m}^{3} / \mathrm{s}$ at its output must be fulfilled.

\section{CONCLUSION}

The CFD approach to the design of the HVAC allows, regardless of the complexity of geometrical area and spatial and time boundary conditions, relatively easy and at the same time, very precise prediction of even very complex fields of velocity, temperature and concentrations formed in the air. Obtaining information about the state functions as desired a large number of points in space, without making prior experimental tests and the space, makes the CFD approach an almost ideal method for designing theventilation and HVAC system.

\section{ACKNOWLEDGMENT}

This paper is made in a scope of the project TR 33047 "Intelligent climate control systems to achieve energy efficient regime in the complex conditions of exploitation" funded by the Ministry of Education, Science and Technological Development of the Republic of Serbia. 


\section{REFERENCES}

[1] $\mathrm{Ng}, \mathrm{K}$. C., Kadirgama, K. and Ng, E. Y. K.: Response surface models for CFD predictions of air diffusion performance index in a displacement ventilated office, Energy and Buildings, Volume 40, Issue 5, pp 774-781, 2008.

[2] Manz, H. and Huber, H.: Experimental and numerical study of a duct/heat exchanger unit for building ventilation, Energy and Buildings, Vol. 32, Issue 2, pp. 189-196, 2000.

[3] Fan, Y.: CFD modeling of the air and contaminant distribution in rooms, Energy and Buildings, Volume 23, Issue 1,, pp 33-39, 1995.

[4] Méndez, C., San José, J. F., Villafruela, J. M. and Castro, F.: Optimization of a hospital room by means of CFD for more efficient ventilation, Energy and Buildings, Volume 40, Issue 5, pp 849-854, 2008.

[5] Banjac, M. and Nikolić, B.: Computational Study of Smoke Flow Control in garage Fires and optimisation of the ventilation system, Thermal Science, Vol. 13, Issue 1, pp 69-78, 2009.

[6] Banjac, M. and Nikolić, B.: Numerical Study of Smoke Flow Control in Tunnel Fires Using Ventilation Systems, FME Transaction, Vol. 36.

[7] Fletcher, C. A. J., Mayer, I. F., Eghlimi, A. and Wee, K. H. A.: CFD as a building services engineering tool, International Journal on Architectural Science, Vol. 2, No. 3, pp. 67-82, 2001.

[8] Adžić, M., Fotev, V., Jovičić, V., Milivojević, A., Milekić, G., Adžić, V. and Bogner, M.: Potentials for Usage of Significantly Reduced Chemical Mechanisms in Numerical Modeling of Combustion Processes, FME Transactions, Vol. 36, No 1, pp. 1-7, 2008.

[9] Banjac, M. and Nikolić, B.: CFD-Simulation der rauchausbreitung und ermittlung der Effizienz von Lüftungsanlagen bei tiefgaragenbränden, Vereinigung zur Förderung des Deutschen Brandschutzes e.V., 58. Jahrgang, Heft 4/2009, pp. 153-159, 2009.

[10]Launder, B. E. and Spalding, D. B.: The numerical computation of turbulent flows, Comp. Meth. in Appl. Mech. \& Eng., Vol.3, pp. 269-275, 1974.

[11] Wilcox, D. C.: Turbulence modeling for CFD, DCW Industries, La Canada, California, USA 1993.

[12] Vasiljević, B. and Banjac, M.: Handbook of Thermodynamics, Faculty of Mechanical Engineering, University of Belgrade, Serbia, 2012.

[13] Sjerčić, M.: Mathematical modeling of complex turbulent transport processes, The Yugoslav Society of Thermal Engineers, Vinča Institute of Nuclear Sciences, Belgrade, 1998

[14] Malalasekra, H. W. and Malalasekera, W.: An Introduction to Computational Fluid Dynamics: The Finite Volume Method, Prentice Hall, 1995.

\section{NOMENCLATURE}

$a_{\mathrm{f}} \quad$ thermal diffusivity for fluid, $a_{\mathrm{f}}=\lambda_{\mathrm{f}} /\left(\rho c_{p}\right)$

$C_{D} \quad$ closure coefficient

$c_{p}$ specific heat capacity at constant volume

$C_{\varepsilon 1} \quad$ closure coefficient

$C_{\varepsilon 2} \quad$ closure coefficient

$C_{\varepsilon 3} \quad$ closure coefficient

$C_{\mu} \quad$ closure coefficient

$F_{i} \quad$ volume forces (gravity force)

$h_{i} \quad$ fluctuating component of enthalpy

$H \quad$ mean specific enthalpy

$k \quad$ turbulent kinetic energy

$P \quad$ pressure of air

$R \quad$ gas constant

$\operatorname{Pr}_{\mathrm{f}} \quad$ Prandtl number

$\mathrm{Pr}_{k}, \quad$ closure coefficient

$\mathrm{Pr}_{\varepsilon} \quad$ closure coefficient

$S_{i j} \quad$ main strain-rate tensor

$T$ air temperature

$U_{i} \quad$ mean velocity components

$u_{i} \quad$ fluctuating velocity components

$x_{i} \quad$ space coordinate

\section{Greek symbols}

$\delta_{i j} \quad$ Kronecker delta function

$\varepsilon \quad$ dissipation rate of turbulent kinetic

energy

$\lambda_{\mathrm{f}} \quad$ thermal conductivity for fluid

$\mu_{\mathrm{f}} \quad$ molecular viscosity

$\mu_{\mathrm{t}} \quad$ eddy viscosity

$\mathscr{k}$ volumetric production rate of $k$

$\rho \quad$ fluid density

$-\rho \overline{h u_{i}} \quad$ Reynolds enthalpy flux

$\vartheta_{\text {in }} \quad$ inlet air temperature

$\sigma_{h} \quad$ closure coefficient

$\tau_{i j} \quad$ Reynolds or turbulent stress $\tau_{i j}=-\rho \overline{u_{i} u_{j}}$

\section{ПРИМЕНА СЕD СИМУЛАЦИЈА ПРИ ПРОЈЕКТОВАҢУ СИСТЕМА ЗА ВЕНТИЛАЦИЈУ И ХЛАЂЕЊА ОБЈЕКАТА СПЕЦИЈАНЕ НАМЕНЕ Милош Бањац}

У овом раду, на примеру пројектовања система за хлађење електро-опреме, смештене у контејнер кранске дизалице МК-46 - "ГОША ФОМ", 
приказана je основна проблематика CFD (Computational Fluid Dynamics) приступа решавању проблема избора одговарајућег расхладног система, те одређивања оптималног положаја, броја и величине отвора за хлађење. Показано је да нумеричка механика флуида, са својом могућношћу, да и пре изградње самог објекта пружи прецизне тродимензионалне слике о брзинским и температурним пољима у флуиду, као и да предвиди промене ових поља које би настале при промени геометрије, граничних и просторних услова (отвора за вентилацију и убацивање и избацивање ваздуха, појединих зидова и преграда), представља супериоран приступ пројектовања ових система. 